\title{
A Study of Marital Adjustment among Alcohol Dependents
}

\author{
Vijay Nayak ${ }^{1}$, Amool Ranjan Singh ${ }^{2}$ \\ ${ }^{1}$ M.Phil. Trainee (Formerly) Department of Clinical Psychology, RINPAS, Ranchi - 834006. \\ ${ }^{2}$ Professor, Department of Clinical Psychology, RINPAS, Kanke, Ranchi - 834006. \\ Corresponding Author: Vijay Nayak
}

DOI: https://doi.org/10.52403/ijrr.20220156

\begin{abstract}
Aims: To Assess and Compare the marital adjustment among alcohol dependent cases and normal control.

Methods: The present study was a crosssectional hospital-based study conducted in the inpatient's department of Ranchi Institute of Neuro-Psychiatric and Allied Sciences (RINPAS), Ranchi. A total of 60 participants were taken for the present study in which 30 participants were alcohol dependent patients diagnosed as per ICD-10 DCR (WHO,1992) criterion and 30 participants were individuals without alcohol abuse taken as normal controls. A purposive sampling technique was used for sample selection. Both the groups were evaluated using a socio-demographic datasheet and Marital Adjustment Questionnaire.

Results and Conclusion: Present study findings revealed that individuals with alcohol dependence have poor Marital Adjustment in respect of the sexual, social, and in emotional area than normal control.
\end{abstract}

Keywords - Alcohol dependence, marital adjustment, sexual adjustment

\section{INTRODUCTION}

Alcohol dependence is a major problem worldwide, India being no exception. Alcohol which was once used as the part of rituals and medicaments now has become a worldwide problem that attracts high attention of mental health professionals (Haglud \& Schuckit, 1992).

Since ager, alcohol use in one or other form has been part of cultural, religious, medicinal and social practices. However, the harmful use of alcohol also results in various major diseases besides violence, crime and injuries it causes, eventually resulting in enormous suffering lives of people.

The harmful use of alcohol is one of the leading risk health factors for the population especially related to maternal and child health domestic violence ingenious disease (viral hepatitis, HIV, Tuberculosis), noncommunicable diseases and mental health related issues etc. (WHO 2018)

Alcoholism is associated with a wide range of mental health problems such as depression, anxiety, drug abuse, and Nicotine dependence and self-harm. There are more than $41 \%$ of suicides are attributable to alcohol and $23 \%$ of people who engage in deliberate self-harm are alcohol dependent (Merrill et al., 1992; Demirbas et al., 2003). Alcohol is a major cause of relationship breakdown, domestic violence and poor parenting, including child neglect and abuse. It is estimated that over 1 million children are affected by parental alcohol misuse and up to $60 \%$ of child protection cases involve alcohol (Prime Minister's Strategy Unit, 2003).

Alcohol abuse increases the feelings of marital distress. Individuals in marriages in which one or both spouses are an alcoholic report higher levels of marital distress or trouble than do married individuals who are not married to 
alcoholics. A study by Cranford et. al (2011) on marital interactions as longitudinal predictors of marital adjustment and it showed that marital adjustment in couples consuming alcohol (either one or both partners) is driven more by wives' alcohol use disorder and marital behavior rather than that of the husband. Another study in India has been done by Ranjan (2018), found significant difference in the domains of sexual, social and emotional adjustment and overall marital adjustment in spouses of individuals having alcohol dependence and that of normal controls. The study also found that males have higher predominance of alcohol use compared to females. Balaganeshan and Ragupathy (2019) conducted a study on marital adjustment, psychological well-being and coping among female spouses of patients with alcohol dependence and found significant amount of less adaptive coping style, poor marital quality and poor psychological well-being in spouses of alcohol dependent patients.

\section{METHODS}

Includes aims /objectives, hypothesis, source of population RINPAS Drug De-Addiction Ward, and selection criteria, participants tools, and techniques used. Detail description of measure used for study and statistical procedure applied with appropriate. statistical procedures.

\section{SAMPLE AND SELECTION CRITERIA OF PARTICIPANT}

A total of 60 male participants were included in the present study. Among whom 30 participants were alcohol dependent patients diagnosed as per ICD-10 DCR (WHO, 1992) criterion who have been admitted in Drug De-addiction Center, RINPAS Ranchi and currently discharged but coming for follow-up periodically Thirty participants were non-alcoholic individuals taken as normal controls. Purposive sampling technique was used for sample selection. Both the groups were matched in respect to various demographic variables, details of education, marital status, duration of marriage, language, residence, family monthly income and types of family.

The patients with duration of intake of 5 years, married for at least 5 years and living together constituted the sample, Participants ranged between age ranges of 25-50 years, educated up to $5^{\text {th }}$ Std or more and who, those who consented for the study.

Inclusion criteria for the normal control subjects was participants ranged between age ranges of 25-50 years, score of less than 3 on GHQ, educated up to $5^{\text {th }} \mathrm{Std}$ or more who consented for the study.

The individuals with alcohol dependent did not have any other significant co-morbid psychiatric disorder, cannabis dependence, Those with Co-morbid chronic physical illness, organic illness and disability or infirmity, Significant side effects of medications. Were also not included in the study.

The control group subjects also did not have any major co-morbid psychiatric or medical conditions.

\section{INSTRUMENTS}

\section{General Health Questionnaire (GHQ-} 12)

The General Health Questionnaire developed by Goldberg and Williams in 1979 has been used. It is 12 items questionnaires. It is four-point scale and scored as $0-0-0-1$ the cut off score is $>3$ is used to identify the psychologically healthy person. It is avidly used to screen for the absence of psychiatric distress. The purpose was Appling GHQ- 12 is to screening psychiatric disorders among the normal control subjects. Reliability coefficient of the questionnaire ranged from 0.78 to 0.95 in different methods.

\section{Marital Adjustment Questionnaire-} Pramod Kr. \& Km. Kanchan Rohatgi, (1999) developed Marital Adjustment Questionnaire and the same was used to examine couples who constituted the sample. The questionnaire is developed in a way as to provide a more meaningful single 
composite marital adjustment score for the couple unlike other available scales which give separate marital adjustment scores for the two. It consists of 25 highly discrimination yes-no type items (Yes-1, No.-0). The questionnaire has good testretest reliability and the face validity appear to be fairly high. The split-half reliability, correlating odd-even items, applying the Spearman-Brown formula for doubling the test length, was found to be.49(n=60) with an index of reliability of .70 .

\section{STATISTICAL ANALYSIS}

The statistical analysis was done with the help of Statistical Package for Social Science-20 (SPSS-20). For the analysis of obtained data Chi Square $\left(\chi^{2}\right)$ and t-test was applied.

\section{RESULTS}

Table showing the scores of Alcohol Dependence Subjects and Normal Control Subjects on Marital Adjustment Scale:

\begin{tabular}{|l|l|l|l|l|l|l|}
\hline \multirow{2}{*}{$\begin{array}{l}\text { Subjects } \\
\text { Variables }\end{array}$} & Alcohol Dependence Patients & Normal Control Subjects & Df & \multirow{2}{*}{ P } \\
\cline { 2 - 6 } & Mean & SD & Mean & SD & & Value \\
\hline Sexual & 2.93 & 1.28 & 4.83 & 1.36 & 58 & $<.001 * *$ \\
\hline Social & 4.60 & 2.47 & 6.43 & 1.50 & 58 & $<.001 * *$ \\
\hline Emotional & 5.13 & 3.02 & 7.06 & 2.08 & 58 & $<.01 * *$ \\
\hline Marital Adjustment Total & $12.66 \quad$ * Significant at 0.01 level & 2.13 & 58 & $<.001 * *$ \\
\hline
\end{tabular}

Table shows the results where the comparison of marital adjustment among the alcohol dependence patients and normal control subjects is reflected. The high score indicates better marital adjustment.

\section{DISCUSSION}

Patients having alcohol dependence lacked adequate sexual pleasure and satisfaction in sexual relationship with spouse. This is because of the fact that the individuals with alcohol dependence have various types of psychosocial, economic. issues and conflicts in self, sex and interpersonal areas as reported by various researchers in the past (Fatima, Panday, \& Rizvi, A. (2015) and Nayak \& Singh (2021).

Further, the individuals with alcohol dependence were not able to spend adequate quality time and maintain healthy interaction with their family members and children. The findings also indicate that as these parameters do not meet necessary requirement, the families of individuals with alcohol dependence are subjected to various deficits in emotional and social growth in day-to-day life.

Emotional area in compare to control group were unable to manage and control his emotion. The table also delineate that control group was significantly better emotional regulation in comparison to individuals with alcohol dependence. The mutual trust and respect were better in control group.

The individuals with alcohol dependence also exhibit various types of issues to do with interpersonal and parenting which is similar to other studies (O'Farrell, Cutter, \& Floyd (1985).

A study of conflict among alcohol dependence case findings revealed that individuals with alcohol dependence have more conflict in respect of the family area, sex area, interpersonal relationship, and self-concept area than normal control. (Nayak. and Singh 2021)

Marital adjustment of patients with substance dependence, schizophrenia and bipolar affective disorder when compared, schizophrenia patients were found to have significantly poor sexual adjustment than substance dependence patients. Patient with bipolar affective disorder have significantly poor sexual and social marital adjustment than patients with substance dependence. Schizophrenia and bipolar affective disorder patients do not significantly differ from on marital adjustment, since majority of the patients with schizophrenia and bipolar affective disorder and $50 \%$ patients with substance dependence have poor marital 
adjustment, marital counselling form a part of the psychosocial management of these patients. (Muke et al., (2014).

Here, it is apparent for the index study that individuals with alcohol dependence have poor quality of married relationship which results in various psychosocial problem eventually faced by farmed.

\section{CONCLUSION}

Present findings indicate that, there was significant difference in marital adjustment in between patients with alcohol dependence and normal control group.it can be drawn that alcohol dependence subject have high as well as poor marital adjustment ability in comparison to normal subjects.

\section{Acknowledgement: None}

\section{Conflict of Interest: None}

\section{Source of Funding: None}

\section{Ethical Approval: Approved}

\section{REFERENCES}

1. Burkhalter, P. 1975. Alcoholism, drug abuse and drug addiction: a study of nursing education. The Journal of nursing education, 14(2), 30-36.

2. Das. R. 2004. A study of global adjustment life satisfaction among spouse of individuals with alcohol abuse. Unpublished manuscript (M. Phil). Department of psychiatric social work, RINPAS.

3. Fatima, N., Panday, R., \& Rizvi, A. 2015. Comparative study of marital adjustment and life satisfaction among spouses of patients with alcohol dependence and normal healthy control: A case control study. Int J Res Med Sci, 3(9), 2246-2251.

4. Goldberg, M. L., Lifton, R. P., Stark, G. R., \& Williams, J. G. 1979. Isolation of specific RNAs using DNA covalently linked to diazo benzyloxymethyl cellulose or paper. In Methods in enzymology (Vol. 68, pp. 206-220). Academic Press.

5. Haglung, R.M.J., \& Schuckit, M.A. 1992. The epidemiology of alcoholism. In N.J Estes \& M.E. Heinemann (Eds.),
Alcoholism: Development, Consequences and Interventions ( $\left.2^{\text {nd }} \mathrm{ed}\right) \mathrm{pp} .32-48 . \quad \mathrm{C} . \mathrm{V}$. Mosby Co, St Louis, MO

6. Jagannath. D. A 2015. Marital adjustment and coping among the spouses of person with alcohol dependence syndrome. Unpublished manuscript (M.Phil). Department of psychiatric social work, RINPAS

7. Jiloha, R. C., \& Soni, S. 1994. Influence of family and marital relationship in alcoholism. Journal of Personality and Clinical Studies.

8. Kearns-Bodkin, J. N., \& Leonard, K. E. 2005. Alcohol involvement and marital quality in the early years of marriage: A longitudinal growth curve analysis. Alcoholism: Clinical and Experimental Research, 29 (12), 2123-2134.

9. Keller, P. S., Mark Cummings, E., \& Davies, P. T. 2005. The role of marital discord and parenting in relations between parental problem drinking and child adjustment. Journal of Child Psychology and Psychiatry, 46(9), 943-951.

10. Kelly, A. B., \& Kowalyszyn, M. 2003. The association of alcohol and family problems in a remote indigenous Australian community. Addictive behaviors, 28(4), 761-767.

11. Kiran.C.\& Chaudhury.S.\& Rani. S \& Chakraborty 2010. Hematology alteration in alcohol dendence published on RINPAS Seminar, 2, 278-283.

12. Moskalenko, V. D., \& Gun'Ko, A. A. 1994. The wives of alcoholics: experience in the study of psychopathology. Zhurnal nevrologii I psychiatric imeni SS Korsakova, 94(1), 51-54.

13. Muke, S. S., Ghanawat, G. M., Verma, A. N., Chaudhury, S., \& Singh, A. R. 2010. Marital Adjustment among Substance Dependence and Bipolar Affective Disorder Patients. 2, 319-324.

14. Murphy, C. M., Winters, J., O'Farrell, T. J., Fals-Stewart, W., \& Murphy, M. 2005. Alcohol consumption and intimate partner violence by alcoholic men: comparing violent and nonviolent conflicts. Psychology of Addictive Behaviors, 19(1), 35.

15. Nayak, V. \& Singh Amool Ranjan (2021). A study of conflict among alcohol dependent cases. International Journal of Scientific Research 10 (9),41-42.

16. O'Farrell, T. J., Cutter, H. S., \& Floyd, F. J. 1985. Evaluating behavioral marital therapy 
for male alcoholics: Effects on marital adjustment and communication from before to after treatment. Behavior therapy, 16(2), 147-167.

17. Sacks, J. M., \& Levy, S. 1950. The Sentence Completion Test.

18. Sacks, Joseph M., and Levy, Sidney. "The Sentence Completion Test." pp. 357-402. (PA 25:2468) In Projective Psychology: Clinical Approaches to the Total Personality. Edited by Lawrence Edwin Abt and Leopold Bellak. New York: Alfred A. Knopf, Inc., 1950. Pp. xvii, 485, xiv.

19. Saxena, S. 1997. Alcohol, Europe and developing countries. Addiction, 92 (Supplement 1), 543-548.

20. Schall, M., Kemeny, A., \& Maltzman, I. 1992. Factors associated with alcohol use in university students. Journal of studies on alcohol, 53(2), 122-136.

21. Weiss, R. L., \& Aved, B. M. 1978. Marital satisfaction and depression as predictors of physical health status. Journal of Consulting and Clinical Psychology, 46(6), 1379.

22. Whisman, M. A., Uebelacker, L. A., \& Bruce, M. L. 2006. Longitudinal association between marital dissatisfaction and alcohol use disorders in a community sample. Journal of Family Psychology, 20(1), 164.

23. WHO) Global status on alcohol and health 2018.

How to cite this article: Nayak V, Singh AR. A study of marital adjustment among alcohol dependents. International Journal of Research and Review. 2022; 9(1): 497-501. DOI: https:// doi.org/10.52403/ijrr.20220156 